\title{
MITŐL ERŐS AZ ALKUPOZÍCIÓ?
}

Az egyik tárgyalófél erős alkupozíciója egy tárgyalás során nagyobb értékelsajátítás lehetőségét teremti meg számára. Az erős alkupozíció két alappilléren nyugszik: erős BATNA és a másik fél rezisztenciapontjára vonatkozó megalapozott becslés. Előbbi a felosztható torta egy részét teszi a másik fél számára hozzáférhetetlenné, utóbbi csökkenti a kemény nyitó ajánlat kockázatait. Az alkupozíció egyértelműen erős, ha mindkét pillér erős, és egyértelműen gyenge, ha mindkettő gyenge. Az egyik-erős-másik-gyenge (közép-erős) helyzetek eltérő tárgyalási taktikákat igényelnek. A gyenge pozíciók közötti alku kimenete a felek kommunikációs (taktikai) ügyességének eredőjén múlik. ${ }^{1}$

Kulcsszavak: disztributív tárgyalás, erős alkupozíció, rezisztenciapont, BATNA (Best Alternative To a Negotiated Agreement), nyitó ajánlat, becslési bizonytalanság

A Harvard Program on Negotiation (PoN) a 1980-as évektől új megközelítést hozott a tárgyalás szakirodalmába. Az ezt megelőző alapirodalmak érdekes két szélsőség felé orientálódtak (és ez a két vonulat mindmáig tetten érhető): az egyik irányzatot erősen matematizált megközelítés jellemezte (lásd pl.: Young, 1975; Raiffa, 1982; Raiffa et al., 2002), a másik a tárgyalás személyközi, pszichoszociális dinamikájának megértésére és a tárgyaló felek számára kedvező befolyásolására helyezte a hangsúlyt (Cohen, 1980; Scott, 1981; Dawson, 1996; Tracy, 2013; Rodgers, 2015). A magyar szerzők munkái az utóbbi vonulatba sorolhatók (Máté, 1995; Blahó, 1999; Körösi, 2001; Neményiné, 2002).

A Harvard PoN egyfelől integrálta ezt a két megközelítést, másfelől felépített egy olyan racionális gondolkodási struktúrát, amely minden tárgyalásra jellemző (Fisher Ury, 1983; Fisher - Brown, 1989; Ury, 1991). Ez a struktúra mindenki által tanulható, nem múlik velünk született vagy tanult interperszonális vagy kommunikációs képességeken, készségeken, adottságokon. Ezt a tárgyalásról való gondolkodási struktúrát több szerző rendszerezte, illetve finomította, tovább fejlesztette (Bazerman - Neale, 1992; Bazerman, 1998; Luecke, 2003; Malhotra - Bazerman, 2007).

Ennek a gondolkodási struktúrának egy fontos eleme az, hogy „,nem erőből, keményen tárgyalunk”, hanem felépítünk egy erős alkupozíciót. Ennek a pontos értelmezéséhez szükséges egy kicsit körül járni a kulcsfogalmak magyar fordítását.

Az egyik lényeges különbségtétel a pozicionális versus érdekalapú tárgyalás.

A PoN modell egyik alaptétele, hogy ,,a mögöttes érdeket nézd, ne a pozíciót" (Fisher - Ury, 1997). A két fogalmat Bazerman és Neale (1992, p. 70.) a következőképpen határolja el egymástól: „A pozíció az egyik fél által kinyilvánított elvárás, amit a másiktól akar megkapni. Az érdek az, amire a felek valójában vágynak, még ha ez nyilvánosan nem is fogalmazódik meg”.

A másik megkülönböztetendő fogalompár a tárgyalás (negotiation) és az alku (bargain). A tárgyalás erőforrá- sok (értékek) elosztása az érdekkülönbségek kezelésével; a tárgyalás során a felek olyan döntésre törekszenek, amely saját érdeküket maximalizálja (Bazerman - Neale, 1992, p. 1.). Az alku némileg szűkebb értelmü fogalom, mint a tárgyalás: míg a tárgyalás értelmezésének része az értékteremtés (aminek elosztásáról szól a tárgyalás), az alku fogalmilag inkább az (adott) értékből való részesedés iránti igény és ennek tényleges megszerzése (https://www. negotiations.com/definition/bargaining/). A cikkben tárgyalt erős alkupozíció gondolatkör az alku és a pozíció értelmezéshez kapcsolódik: a tárgyalás folyamán a felek milyen érték megszerzésére formálnak igényt, és mi az, ami növeli az esélyeiket arra, hogy ezt az igényt minél erőteljesebben tudják megfogalmazni és azt ezután el is tudják érni.

A tárgyalás szakirodalmában közhelyszerü állítás az, hogy az erős alkupozíció birtokosa a megszerezhető előnyök nagyobb részét tudja megszerezni (vagy a disztributív tárgyalások népszerü metaforájával élve a torta nagyobb szeletét tudja kihasítani magának). Az erős alkupozíció előnyei átfogóbb elméletekben is felbukkannak - nagyon hasonló végkövetkeztetésekkel. Porter öt erő modelljében az erős alkupozícióban lévő fél mind a vevői, mind az eladói oldalon - ezek önmagukban is tekinthetök tárgyalási helyzeteknek - a maga teremtette értéket meghaladó érték elsajátítására válik képessé (Porter, 2008).

Amennyire egyértelmü az „erős alkupozíció előnyös” tételnek a trivialitása, annyira hiányzik a mértékadó szakirodalmi forrásokban annak bemutatása, hogy mitôl erős egy alkupozíció, hogy pontosak legyünk, ezekben a forrásértékủ munkákban az erős alkupozíció elemeit bemutatják és tárgyalják, de ezek sehol sincsenek egységes keretmodellbe rendezve. Talán jó indikátora ennek az a tény, hogy kézikönyvszerűen használt források kulcsszó jegyzékében sem találjuk meg az erős alkupozíció (strong bargaining power) kifejezést - ennek ,belátását az olvasóra bízzák".

Tanulmányomban erre szeretnék választ adni, felhasználva a tárgyalás irodalmából egyébként ismert fogalmakat, ám új módon kombinálva azokat. A cikkben kibon- 
takozó keretmodellnek tehát lényegében minden eleme ismert, a szerző előtt ugyanakkor nem ismeretes olyan publikáció, amelyek mindezeket az itt bemutatandó modellbe összerendezve tárgyalná.

Elméleti jellegü és igényü tanulmányomban arra vállalkozom tehát, hogy a szakirodalmi forrásokban az alkupozíció erősítésére vonatkozó utalásokat egy keretmodellbe rendezve - ,jogász-nyelven szólva": egységes szerkezetben - bemutassam, hogy az alkupozíció erősítésének a megegyezési zóna mindkét végpontjára vonatkozó felismerései, részismeretei együtt hogy határozzák meg az erős alkupozíciót. Gondolatmenetem újszerü eleme továbbá az az alkupozíció erősségére vonatkozó finomhangolt értelmezés, amely azokat a helyzeteket diszkutálja, amikor a megegyezési zóna két végpontjának alkuerő szempontjából való megítélése eltérő (azaz amikor az egyik alku ereje erős, a másik viszont gyenge).

\section{A DISZTRIBUTÍV TÁRGYALÁS ALAPMODELLJE}

A tárgyalás egymásra utalt, de eltérő érdekekkel (értékekkel, preferenciákkal) rendelkező felek közötti kommunikáció és döntés, ahol

- az egymásrautaltság azt jelenti, hogy a felek kölcsönösen kontrollálnak valamit, amire a másiknak szüksége van - és ezek kicserélésével mindketten várhatóan jobban járnak, mintha ugyanazt más módon próbálnák megszerezni,

- a kommunikáció célja az önérdek artikulációja és a saját alkupozíció erősségének felmutatása, illetve a másik fél érdekének feltérképezése és alkupozíciójának gyengítése,

- a döntés pedig a felek megállapodása a megszerezhető értékek egy kölcsönösen elfogadható - ámbár nem feltétlenül kiegyensúlyozott - szétosztásáról. (Ez a döntés lehet nemleges, amennyiben az utolsó érvényes szétosztási ajánlat az egyik fél számára már nem elfogadható.)

Disztributívnak tekintjük azokat a tárgyalásokat, amelyekben a felek egy adott (összegü) érték szétosztásáért versenyeznek és amelyek egyetlen tényezőről (rendszerint az árról) szólnak (Raiffa, 1982, p. 33.). A játékelméletből kölcsönzött kifejezéssel az ilyen tárgyalások zéró összegü játszmák (Neumann - Morgenstern, 1944). A disztributív tárgyalás alaplogikája szerint az egyik fél nyeresége a másik fél veszteségével azonos - azaz csak a másik fél rovására növelhető a saját nyereség (Raiffa, 1982, p. 14.; Luecke, 2003, p. 3.; Malhotra - Bazerman, 2007, p. 52.).

A disztributív tárgyalás során a kulcskérdés: ki, mekkora értékre formál jogot és ki, mekkora értéket szeretne megszerezni (Malhotra - Bazerman, 2007, p. 16.)? A disztributív tárgyalás racionálisan felépíthető modelljének alapsémája és annak kulcsfogalmai jól ismertek - itt csak a további gondolatmenet megalapozása céljából foglalom össze röviden azokat.

- Mindkét fél a maga induló álláspontjának közlésével indítja a tárgyalást - ezeket nyitó ajánlatoknak fogom nevezni (Malhotra - Bazerman, 2007, p. 27.), a két elhangzó nyitó ajánlat feszíti ki a tárgyalási zónát.

- A felek a tárgyalás megkezdése előtt megfogalmaznak egy rezisztenciapontot - ameddig hajlandók elmenni a megállapodás keresés folyamatában. Ez az a közömbösségi pont, ahol szabadon mérlegelem azt, hogy megegyezzek-e vagy megegyezés nélkül kilépjek a tárgyalásból (Bazerman - Neale, 1993, p. 68.). A rezisztenciapontnak több megnevezése is ismert a szakirodalomban: reservation price, walk-away price (Bazerman, 1998; Raiffa et al., 2002; Luecke, 2003).

- A két rezisztenciapont feszíti ki a megegyezési zónát (ZOPA - Zone of Possible Agreement), amelynek teljes tartománya megegyezés szempontjából mindkét fél számára elfogadható, kielégítő (Luecke, 2003, p. 24.), a tartományon kívüli pontok azonban az egyik fél számára bizonyosan nem elfogadhatók (Malhotra - Bazerman, 2007, p. 23.). A ZOPA közkeletü metaforája az adottnak tekintett torta ${ }^{2}$ (Bazerman, 1998, p. 128.) - a felek törekvése pedig az, hogy a tárgyalás ennek a tortának minél nagyobb részét megszerezzék maguknak.

- A rezisztenciapont meghatározásához fontos kapaszkodó a BATNA (Best Alternative To a Negotiated

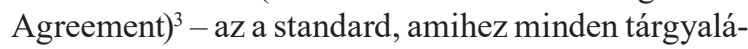
si ajánlatot mérni tudunk (Fisher - Ury, 1983, p. 100.). Ez tulajdonképpen menekülő opció: mit tennék, ha az adott tárgyalásban nem tudok elfogadható eredményt elérni (Raiffa, 1982, p. 252-253.). A BATNA egyfajta benchmark-ként szolgálhat a rezisztenciapont meghatározásához - az adott tárgyalás során nem fogadok el gyengébb megállapodást, mint a külső („,menekülő”) opció (Bazerman - Neale, 1993, p. 67-68.).

Ezeknek a fogalmaknak segítségével felvázolható a disztributív tárgyalás racionális alapsémája (lásd 1. ábra).

\section{1. ábra}

\section{A tárgyalás racionális alapmodellje}

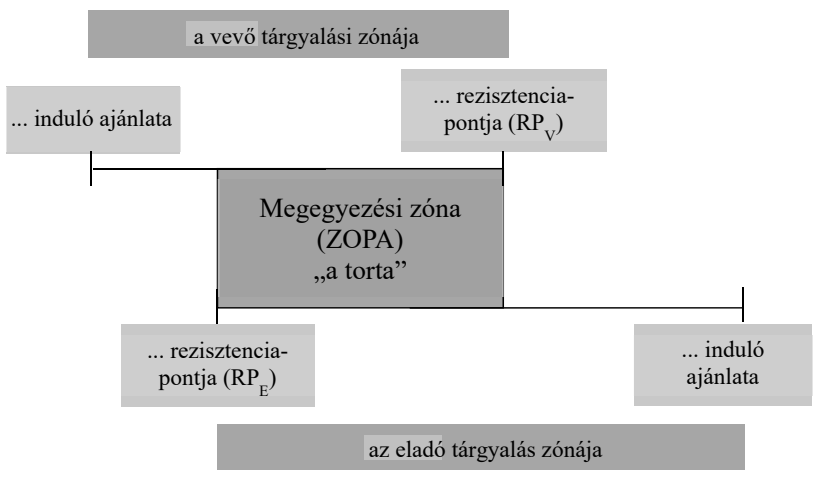

Forrás: (Bakacsi, 2015, p. 143.) alapján $\left(R P_{V}=\right.$ vevő rezisztenciapontja, $R P_{E}=$ eladó rezisztenciapontja

Ezen alapséma keretei között pontosan leírható a disztributív tárgyalás folyamata is, amelyet követve - ha eltérő ritmusban is, de - minden tárgyalás ugyan azokon a szakaszokon megy keresztül (lásd 2. ábra): 
- az induló álláspontok (nyitó ajánlatok) rögzítése ${ }^{4}$,

- a másik fél rezisztenciapontjának kitapogatása,

- a két rezisztenciapont ismeretében a megegyezési zóna rögzítése, és végül

- a megegyezési zónán belül a lehetö legkedvezőbb az adott fél számára elérhető legnagyobb tortaszeletet eredményező - megállapodás elérése ${ }^{5}$.

\section{A disztributív tárgyalás folyamata}

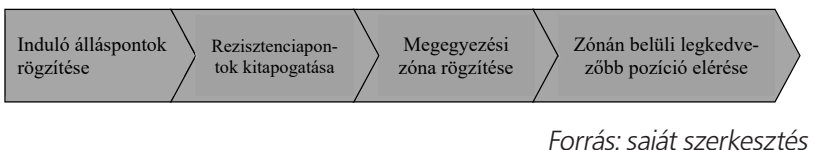

\section{ERŐSÍTI AZ ALKUPOZÍCIÓT?}

A disztributív tárgyalás alapfogalmainak áttekintése után vegyük górcső alá tanulmányom központi kérdését: az erős alkupozíciót!

Ahhoz, hogy az erős alkupozíció modelljét felépítsük, célszerü finomítani az 1. ábrán látható megegyezési zóna modelljét. Ennek oka az, hogy a zóna egyik végpontját határozottan tudjuk (hiszen a folyamat egy korábbi pontján a saját rezisztenciapontot meghatároztuk és rögzítettük), a másik fél rezisztenciapontja azonban nem ismert, arról csak sejtésünk lehet - ahogy Raiffa fogalmaz: erről csak valószínűségi alapú ${ }^{6}$ és valószínűség eloszlás természetű információnk van (Raiffa, 2003, p. 46.). A szakértői becslés ezt a bizonytalanságot - ha teljes mértékben kiküszöbölni nem is tudja, de - képes mérsékelni (Bazerman Neale, 1993, p. 105.).

A disztributív tárgyalás esetén egyik félnek sem áll érdekében felfednie a saját rezisztenciapontját, ez tudniillik a zéró összegü játszma asszertív nyer-veszít logikája alapján tárgyaló partnerét arra csábíthatja, hogy a másik fél utolsó (még éppen elfogadható) megoldása ismeretében megkísérelje őt a felfedett rezisztenciapontra szorítani azaz megszerezni az egész tortát.

Minél nagyobb a bizonytalanságunk arról, hogy hol a másik fél rezisztenciapontja, annál szélesebb tartományban szóródik a torta másik szélére vonatkozó sejtésünk. És megfordítva: minél több előzetes információ támasztja alá a másik fél rezisztenciapontjára vonatkozó sejtésünket (azaz e tekintetben a bizonytalanságunk kicsi), annál kisebb szórástartományban becsüljük a torta másik szélét. A szórástartomány távolabbi széle egy optimistább (vérmesebb), a közelebbi széle pesszimistább (óvatosabb) becslést jelent. Az optimista becslés nagyobbnak, az óvatosabb kisebbnek mutatja a tortát - a szórás pedig lefedi azt a bizonytalansági tartományt, amelyen belül a tényleges rezisztenciapontot sejtjük. A másik fél rezisztenciapontjára vonatkozó sejtésünk bizonytalansága tehát a torta nagyságára vonatkozó becslésünk bizonytalanságában csapódik le.

Itt és a gondolatmenet kifejtése során minden további esetben a megegyezési zónát rendre az Eladó nézőpontjából szemléljük, a saját rezisztenciapontra vonatkozó egyértelmü rögzítettséggel és a Vevő rezisztenciapontjára vonatkozó kisebb-nagyobb bizonytalanságú becsléssel. A következtetések logikai szimmetriája miatt - és a kettős levezetésből adódó redundancia elkerülése érdekében - a vevői nézőpontú bizonyításokat mellőzöm: a fordított (vevői nézőpontból levezett) következtetések ugyanakkor ez alapján könnyen beláthatók.

Így az 1. ábra logikailag egyértelmü megegyezési zónájának ábrázolása valójában két alesettel ábrázolható:

1. az egyik az, ha kis bizonytalansággal, szűk szórástartományban tudjuk becsülni a Vevő rezisztenciapontját (lásd: 3. ábra), a kis bizonytalanságot az alapozhatja meg, hogy a tárgyalásra való felkészülés során előzetesen megbízható információkat sikerült szereznünk a Vevő rezisztenciapontjáról,

3. ábra

\section{A biztos méretű torta a Vevő rezisztenciapontjára} vonatkozó megalapozott sejtéssel

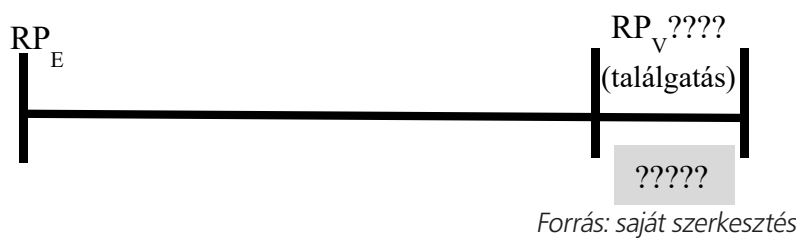

2. a másik az, ha nagy bizonytalansággal, széles szórástartományban tudjuk becsülni a másik fél rezisztenciapontját (lásd: 4. ábra). A nagy bizonytalanság hátterében az húzódhat meg, hogy a tárgyalásra való felkészülés során előzetesen nem sikerült információt szereznünk a másik fél rezisztenciapontjáról, vagy a megszerzett információk megbízhatóságáról nem vagyunk meggyőződve.

4. ábra

A bizonytalan méretű torta a másik fél rezisztenciapontjára vonatkozó nagy szórástartományú sejtéssel

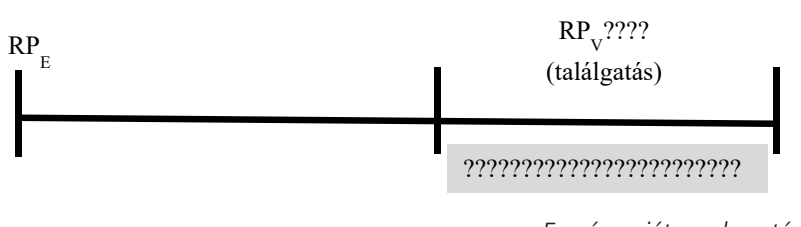

Forrás: saját szerkesztés

A szakirodalom ugyancsak tárgyalja azt, hogy hogyan érdemes „,belőni” az induló ajánlatot (Thompson, 2008). A nyitó ajánlat logikailag három féle lehet: mérsékelt, kemény és eltúlzott (extrém):

- mérsékeltnek tekinthető a nyitó ajánlat akkor, ha azt az Eladó az észlelt megegyezési zónán belül, azaz a Vevő vélt, sejtett rezisztenciapontjához képest a saját rezisztenciaponthoz közelebb fogalmazza meg,

- keménynek nevezzük azt a nyitó ajánlatot, amelyik a megegyezési zónán kívül, ám a Vevő rezisztenciapontján éppen csak túl fogalmazódik meg, és végül 
- eltúlzott (extrém) az a nyitó ajánlat, amely a megegyezési zónán kívül, ám a Vevő rezisztenciapontján messze túl fogalmazódik meg.

A három eltérő típusú nyitó ajánlatot az 5. ábra szemlélteti.

5. ábra

A mérsékelt, a kemény és az eltúlzott nyitó ajánlat

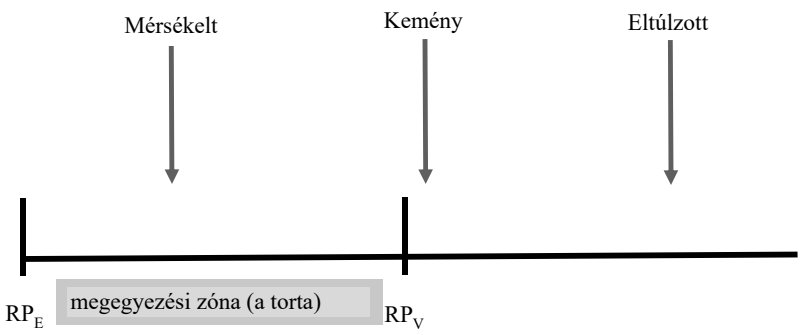

Forrás: saját szerkesztés

A mérsékelt ajánlatot egyértelműen tárgyalási hibának tekinthetjük, hiszen ha az Eladó nyitó ajánlata a Vevő tudott/sejtett rezisztenciapontjától az Eladóé felé esik azaz az észlelt tortán belül van -, akkor ezen ajánlat következménye az, hogy Eladó helyből lemondott az amúgy megszerezhető torta egy részéröl (Malhotra - Bazerman, 2007, p. 34.).

A kemény nyitó ajánlat éppen ezt kerüli el: a rezisztenciaponton éppen kívül eső ajánlattal Eladó a teljes tortaméretet „nyitva hagyja” a tárgyalásra és helyből nem mond le egyetlen morzsájáról sem - jóllehet az már a felek tárgyalóképességén múlik, hogy ténylegesen mennyit tudnak megszerezni belőle. A legendásan sikeres tárgyaló, Henry Kissinger ezt így fogalmazta meg: „Ha a megegyezés rendszerint a két induló ajánlat között születik meg, nem célravezető mérsékelt ajánlattal kezdeni. A jó tárgyalási technika az, ha a kiindulópontod jócskán túl van azon, amit a másik fél hajlandó elfogadni.” A logikai érv mellé tehető egy azt erősítő pszichológiai tényező is: „Minél erőteljesebb a nyitó ajánlatod, annál jobb az esély arra, hogy az, amit a másik el akar érni, azt jó kompromisszumnak érzékelje" (Kissinger, 1961, p. 205.).

Az eltúlzott nyitó ajánlat is „tudja azt”, hogy a teljes tortaméretet tárgyalási alapnak tekinti, ez esetben azonban a kemény ajánlathoz képest lényeges különbség, hogy míg előző - minden keménysége ellenére - hiteles, addig az eltúlzott ajánlatot a Vevő jó eséllyel hiteltelennek (extrémnek, asszertívnek) fogja észlelni (Malhotra - Bazerman, 2007, p. 35.). A hiteltelenségnek pedig két lényeges következménye lehet:

a. a Vevő vagy azonnal kiszáll a tárgyalásból (,ez még tárgyalási alapnak sem megfontolható”), vagy

b. folytatja, de a tárgyalási folyamat onnantól a mély bizalmatlanság medrében folyik tovább.

Amennyire logikai értelemben világos a különbség a kemény és az eltúlzott ajánlat között, annyira nehéz gyakorlatilag megtalálni a helyénvaló keménységet. A két fogalmilag elhatárolható kategória közötti gyakorlati különbségtétel ugyanis lényegileg észlelési probléma: amit az Eladó kemény induló ajánlatnak szán és hitelesnek tekint, azt a Vevő észlelheti eltúlzottnak, hiteltelennek, extrémnek. Ehhez kapcsolódnak a tárgyalók kemény ajánlattétellel kapcsolatos félelmei: inkább vállalják az elmaradó hasznot, mint az extrém, hiteltelen, asszertív megítéltetés pszichológiai stresszének kockázatát. („Inkább vesszen a megszerezhető torta egy része, semmint hogy durvának, agresszívnek tartsanak.”) A helyénvalóan kemény nyitó ajánlat ezért alapvetően fejben dől el: a tárgyalás során nem várhatjuk, hogy megkapunk valamit, aminek kérésére nem vagyunk felkészülve.

\section{AZ ERŐS ALKUPOZÍCIÓ - A KERETMODELL}

Az elméleti háttér tisztázását követően megfogalmazom tanulmányom központi tételét:

Tétel 1: az Eladó erős alkupozíciója két pilléren nyugszik: az Eladó erős BATNÁ-ján és a Vevö rezisztenciapontjára vonatkozó megbizhatóan jó becslésén.

$\mathrm{Az}$ erōs BATNA (egy gyengébb BATNA-hoz képest) azért teszi az Eladó alkupozícióját erőssé, mert a felosztható torta egy része már elvitathatatlanul az övé. Vevő rezisztenciapontjának pontos becslése pedig azzal teszi erőssé Eladó alkupozícióját, hogy jelentősen csökkenti Eladó kemény nyitó ajánlatának kockázatait.

Nézzünk egy kicsit részletesebben a két állítás mögé!

\section{Az Eladó erős BATNA-ja mint alkupozíciót erősítő tényező}

A tárgyalásra való felkészülés egyik legerősebb „aranyszabálya", hogy BATNA nélkül ne bocsátkozzunk tárgyalásba. Fentebb már utaltunk arra, hogy a BATNA a rezisztenciapontunk meghatározása szempontjából benchmark-ként használható.

Itt érdemes a tétel megfordításából kiindulni: mi van akkor, ha Eladónak egyáltalán nincs BATNA-ja? BATNA hiányában Eladó lényegében kiszolgáltatott helyzetben van, különösen akkor, ha ezzel Vevő tisztában is van. A BATNA hiányában Eladó alkupozíciója végletesen gyenge: ha Vevő tudja, hogy Eladónak nincs menekülö opciója (azaz vagy az adott tárgyalás eredményeként szerzi meg azt, amit akar, vagy sehogyan) akkor a legvalószínübb tárgyalási kimenet az, hogy a megállapodás Eladó rezisztenciapontján jön létre. Ez gyakorlatilag azt eredményezi, hogy Vevő ,viszi az egész tortát”, Eladó pedig a megegyezési zóna utolsó, még éppen elfogadható pontját kénytelen tudomásul venni. A kiszolgáltatott helyzet következménye olykor még ennél is súlyosabb lehet: ha Vevő kellően agresszív, akkor Eladót az előre eldöntött rezisztenciapontja feladására kényszerítheti - így Vevő nemcsak a tortát viszi, de még ,a spájzba is benyúl” és olyan értékeket is megszerez magának, amelyek korábban már Eladóé voltak.

A „BATNA nélkül sose ülj tárgyalóasztalhoz” főszabályon túl bizonyítani fogom, hogy annak is van jelentősége, Eladó BATNA-ja mennyire jó.

Induljunk ki egy létező, de nem különösebben erős menekülő opcióból (BATNA-ból): ennek létezése elejét 
veszi annak, hogy Eladó kiszolgáltatott helyzetből tárgyaljon, egyben támpontot jelent rezisztenciapontja meghatározásában is, hiszen ennél rosszabb ajánlatot Eladó az adott tárgyalásban sem fog megfontolni.

Mi a következménye annak, ha Eladónak van egy ennél jobb BATNA-ja?

A fentebbi gondolatmenetet követve a jobb BATNA erősebb rezisztenciapont rögzítését teszi lehetővé. A gyengébb BATNA relatíve nagyobb tortamérettel jár, az erősebb BATNA kisebb tortát eredményez. Az erősebb BATNA jelentőségét akkor értjük meg teljes egészében, ha feltesszük a kérdést: kié a két tortaméret közötti különbség? A válasz egyértelmü: Eladó erősebb BATNA-ja következtében adódó erősebb rezisztenciapont a korábbi nagyobb torta egy részét már elérhetetlenné teszi Vevő számára, az már ,helyből az Eladóé”, és a tárgyalási alkufolyamat innen kezdődik:

- általában: ha a tárgyaló felek kiegyensúlyozott eröpozícióját feltételezzük, akkor a legvalószínübb megegyezési kimenet a „középen való megegyezés”, a torta felezése,

- konkrét esetben: továbbra is feltételezzük azt, hogy az Eladó az erősebb BATNA-ra alapozott kisebb tortának is a felét tudja megszerezni, ehhez azonban hozzáadódik a már eleve „,birtokon belül került” tortarésze, így az Eladó által megszerzett összérték az erősebb BATNA révén nőtt,

- a gondolatmenet megfordításából viszont az következik, hogy amennyiben Vevő rendelkezik erös BATNA-val, akkor e rezisztenciaponton kívüli tartomány Eladónak válik hozzáférhetetlenné, az már „,helyből Vevőé”.

A gyengébb, illetve erösebb BATNA alapján megszerezhető értéktöbbletet a 6 . ábrán szemléltetve mutatom be.

\section{A gyenge és az erősebb BATNA következménye a megszerezhető torta méretére}

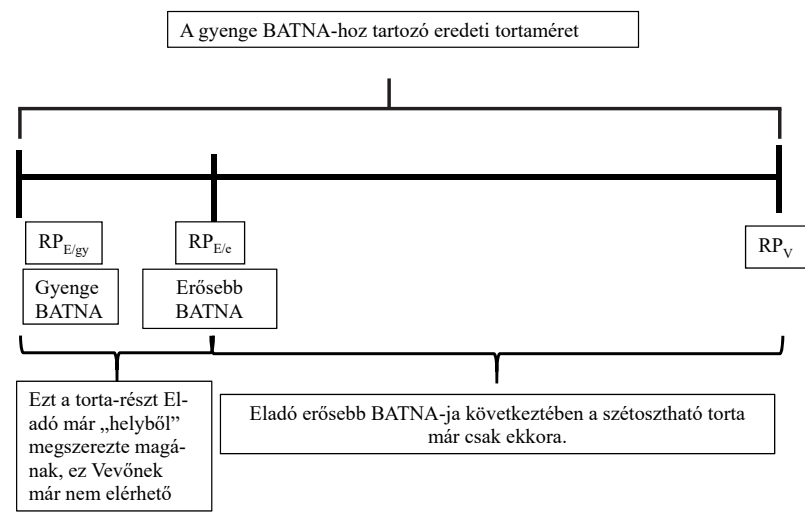

Forrás: = saját szerkesztés $\left(R P_{E / q y}=\right.$ az eladó gyengébb BATNA-ra alapozott rezisztenciapontja, $R P_{E / e}=$ az eladó erősebb BATNA-ra alapozott rezisztenciapontja)

A fentiek alapján feltehetjük a kérdést, hogy mi a jobb: ha kicsi a torta, vagy ha nagy? A választ további négy fontos segédtétel megfogalmazásával adhatjuk meg:
Tétel 2a: ha a torta azért kicsi, mert Eladó BATNA-ja erős, akkor ez az Eladó erős alkupozícióját eredményezi és számára nagyobb értékelsajátítást tesz lehetővé,

Tétel $2 b$ : ha a torta azért kicsi, mert Vevő BATNA-ja erős, akkor ez az Eladó gyenge alkupozícióját eredményezi és Vevő számára tesz lehetővé nagyobb értékelsajátítást,

Tétel 2c: a legkisebb tortaméretet az eredményezi, ha mind Eladó, mind vevő erős BATNA-ra támaszkodva tárgyal, ilyenkor az értékelsajátítás azért lesz szimmetrikus, mert erős rezisztenciapontja révén mindkét fél eleve megszerzett már magának értéket, ehhez adódik hozzá a kis torta feletti osztozkodás révén megszerezhető többletérték,

Tétel 2d: a nagy tortaméret ugyanakkor mindkét fél relatíve gyenge alkupozíciójának (gyenge BATNA-jának és nagyfokú bizonytalansággal jellemezhető becslésének a jele). Ilyen helyzetben a tárgyalás sikere a taktikai elemeken múlik: melyik félnek sikerül rátapintania a másik fél gyenge pontja(i)ra, illetve mennyire tudja rejtve tartani a saját gyengesége(i)t.

Itt egy rövid kitérő erejéig utalok arra, hogy a tárgyalási dinamika fontos eleme és az alkupozíció erősítésének egy további módja lehet az is, hogy Eladó miként képes gyengíteni Vevő BATNÁ-ját. Ez nem azonos Vevő BATNA-ja becslésének bizonytalanságával, itt inkább arról van szó, hogy Eladó képes-e Vevő biztosnak vélt BATNA-ját elbizonytalanítani (például a BATNA alapjául szolgáló menekülő opció Vevőre kedvezőtlen következményű befolyásolásával). Ennek a taktikai mozgástérnek további eleme mindennek a fordítottja: Eladó képes-e felismerni azt, hogy Vevő mivel szándékozik gyengíteni Eladó BATNA-ját, és Eladó tud-e olyan manővert kidolgozni, amivel a BATNA-nak ezt a gyengítési kísérletét kivédi. Ezek a taktikai elemek önmagukban képesek a torta méretének megváltoztatására (növelésére vagy csökkentésére). Ezekre azonban itt csak utalok - részletes kifejtésük szétfeszítené jelen tanulmány terjedelmi korlátait.

\section{Vevő rezisztenciapontjának pontos becslése mint alkupozíciót erősítő tényező}

Vegyük górcső alá most a megegyezési zóna másik szélét, Vevő rezisztenciapontját. Fentebb már utaltunk arra, hogy:

a. ennek becslése lehet megalapozott (kis bizonytalanságú, kis szórástartományú), illetve bizonytalan (nagy szórástartományú, hiányos vagy megalapozatlan információkon alapuló),

b. az ideális nyitásnak Eladó kemény, de hiteles induló ajánlatát neveztük.

Kapcsoljuk össze a kettőt!

Amennyiben Vevő rezisztenciapontjának becslése nem egyetlen határozottan megadható pont (ahogy azt az 5. ábra sejteti), hanem azt Eladó egy kisebb-nagyobb szórástartományú zónában sejti (lásd: 3. és 4. ábra), akkor Eladó kemény nyitó ajánlatának meghatározása kapcsán felmerül egy komoly dilemma. Nevezetesen az, hogy ha a kemény ajánlatnak Vevő rezisztenciapontján egy kicsit túl kell lennie, akkor e tekintetben Eladó a becslési tartomány 
melyik szélét tekintse irányadónak: az optimistát (vérmesebbet) vagy a pesszimistát (óvatosabbat)?

A dilemma középpontjában az áll, hogy valójában Vevő rezisztenciapontja ténylegesen hol van: az Eladó által becsült tartomány optimista vagy a pesszimista széléhez közelebb?

Ha a szórástartomány relatíve szük, akkor Eladó dilemmája kevésbé feszítő, hiszen ha - a föszabályt követve - Eladó nyitó ajánlata saját optimista becslésén még egy kicsit kívül van, ugyanakkor Vevő rezisztenciapontja ténylegesen a pesszimista becsléshez van közelebb, akkor is kicsi a kockázata annak, hogy Eladó nyitó ajánlata elveszti hitelességét és Vevő azt már eltúlzottnak, extrémnek észleli.

Ha azonban Eladó becslési szórástartománya nagy, akkor dilemmája kézzelfoghatóvá válik. Ilyen esetben már valós tétje van annak, hogy Eladó ajánlata optimista vagy pesszimista kiinduló pontú-e, ugyanis mindkettőnek van kockázata. A dilemmát az teszi valóságossá, hogy a két kockázat eltérő logika szerint értelmezhető. Vegyük sorra ezt a két eltérő típusú kockázatot!

\section{Eladó optimista induló ajánlatának kockázata}

Ha Eladó az induló ajánlata megfogalmazása során optimista módon a maga bizonytalan becslési zónájának legtávolabbi - azaz Eladó szempontjából legkedvezőbb - pontjából indul ki, és ajánlata szándékoltan kemény, akkor ez az optimistán megítélt ponton egy kicsit túl fogalmazódik meg (lásd: 7. ábra).

Eladó optimista nyitó ajánlatának kockázata Vevő rezisztenciapontjának bizonytalan becslése esetén

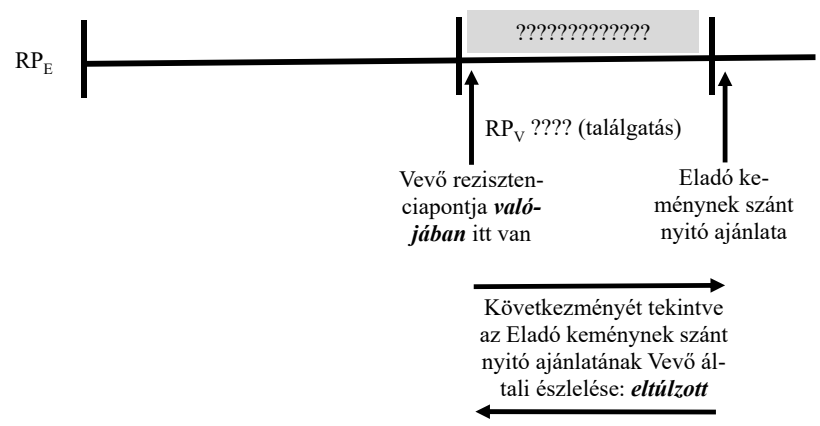

Forrás: saját szerkesztés

A kockázat ilyenkor az, hogy Vevő rezisztenciapontja ténylegesen a bizonytalanul becsült zóna átellenes szélénél van - ebben az esetben ugyanis Eladó keménynek szánt induló ajánlatát Vevő már eltúlzottnak észlelheti, annak minden következményével. Ami tehát Eladó szempontjából logikus - a követett elv tudniillik az, hogy ajánlatával helyből ne mondjon le a megszerezhető torta semekkora részéröl - az a Vevő szempontjából más megítélés alá esik: Eladó ajánlatát eltúlzottnak, hiteltelennek észleli és arra vagy elutasítóan válaszol, vagy benne marad ugyan a tárgyalásban, de annak folyamatát részéről már az Eladó iránti alapvető bizalmatlanság terheli meg.

\section{Eladó pesszimista induló ajánlatának kockázata}

Ha Eladó az induló ajánlata megfogalmazása során az óvatosság okán, pesszimista módon a bizonytalan becslési zóna legközelebbi - Eladó szempontjából legkedvezőtlenebb - pontjából indul ki, és ajánlata ehhez képest szándékoltan kemény, akkor a kockázata abból adódik, hogy Vevő rezisztenciapontja ténylegesen a bizonytalanul becsült zóna átellenes szélénél van. Ebben az esetben ugyanis Eladó keménynek szánt induló ajánlata valójában mérsékeltnek fog bizonyulni, azaz helyböl lemondott a megszerezhető torta egy részéről (lásd: 8. ábra). Ami Eladó szándékát tekintve óvatosság, az a következményeket tekintve Eladó elmaradó haszna.

8. ábra

Eladó pesszimista nyitó ajánlatának kockázata Vevő rezisztenciapontjának bizonytalan becslése esetén

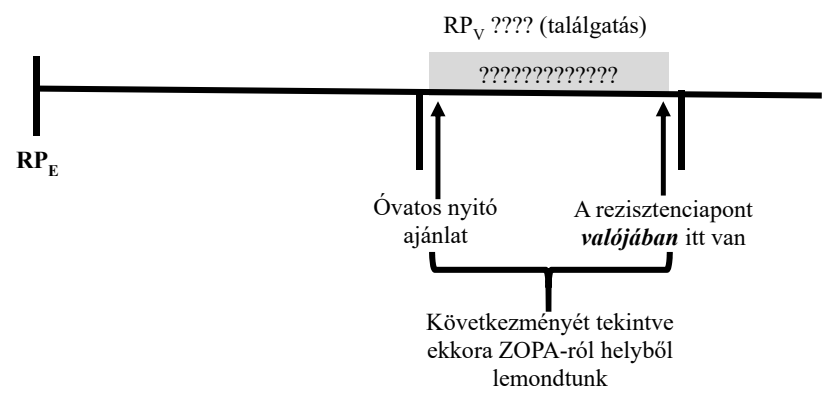

Forrás: saját szerkesztés

Fentiek alapján feltehetjük a kérdést, hogy Eladó számára mi az elönyösebb akkor, ha Vevő fél rezisztenciapontját csak bizonytalanul, nagy szórási tartományon belül tudja becsülni: rámenőssebben, vérmesebb reményeket követve fogalmazza meg nyitó ajánlatát, vagy éppen ellenkezőleg óvatosan járjon el? A választ további három fontos segédtétel megfogalmazásával adhatjuk meg:

Tétel $3 a$ : mind az optimista, mind a pesszimista megközelítés kockázatos lehet Eladó számára. Eladó alkupozíciója ennek folytán gyenge és ennek folytán a gyenge alkupozíció esetén követendő szabályokat célszerü alkalmaznia,

Tétel 3b: ilyenkor helyénvalóbb, ha Eladó kivár, és nem elsőként tesz ajánlatot, hanem megvárja a Vevő fél ajánlatát és arra reagál - második ajánlattétellel ${ }^{8}$,

Tétel 3c: Eladó tárgyalásra való felkészülése során ugyanakkor hangsúlyosan törekednie kell Vevő rezisztenciapontjának minél pontosabb becslésére, a bizonytalan becslési tartomány szükítésére - ennek eredményeként gyenge alkupozícióját erősítheti.

\section{Összefoglalás és következtetések}

Eladó alkupozíciójának erőssége/gyengesége szoros logikai kapcsolatban áll a megegyezési zóna két szélével kapcsolatos bizonyosságaival/bizonytalanságaival.

A fenti gondolatmeneteket összefoglalva - és a Tétel 1-et egy kicsit részletesebben kibontva. 
- a legerősebb, legstabilabb alkupozíció az, ha a tárgyalás során Eladó támaszkodni tud mind egy erős BATNA-ra, mind a Vevő rezisztenciapontjának megbízható, pontos becslésére,

- ezzel szemben Eladó alkupozíciója egyértelmüen gyenge, ha a BATNA-ja gyenge (még inkább, ha nincs) és a Vevő rezisztenciapontjára vonatkozó becslése is bizonytalan, pontatlan (csak hiányos tényekre és megbízhatatlan információkra alapozható),

- érdekes elemezni a közbülső helyzeteket, nevezetesen amikor a két tényező közül az egyik erős, a másik gyenge. Ilyenkor az alkupozíció közép-erös (félig erös/félig gyenge):

- ha Eladó BATNA-ja erős, ám a Vevő rezisztenciapontjára vonatkozó becslése bizonytalan, akkor Eladó alkupozíciójának gyengeség abban nyilvánul meg, hogy nem célszerű elsőként induló ajánlatot tenni, ugyanakkor a tárgyalás folyamatában úgy támaszkodhat az erôs BATNA-jára, hogy a kölcsönös engedmények megadása során Vevő engedményeire maga kisebb engedmények megadásával válaszol,

- ha Eladó BATNA-ja gyenge, ugyanakkor a Vevő rezisztenciapontjára vonatkozó becslése megbízható, pontos, akkor Eladó lehet kezdeményező az elsőként megfogalmazott és kemény ajánlattal, aminek következtében egy kellően nagy ZOPA-t észlel. A gyenge BATNA azonban Eladót óvatosságra kell, hogy intse - különösen, ha a ,gyenge menekülő opciója" Vevő számára is nyilvánvaló. Ennek ugyanis lehet az a végeredménye, hogy Vevő - kellő felkészültséggel és agresszív tárgyalási taktikával ennek a nagy tortának a nagyobb részét kihasítja magának.

A tárgyalási siker összességében két tényezőn múlik: az egyiket nevezhetjük stratégiainak, a másikat taktikainak:

- a stratégiai tényező egyértelműen a tárgyalásra való felkészülés folyamatában gyökerezik - mennyire sikerül egy erős tárgyalási pozíciót felépíteni (erős BATNA felépítésével, illetve a másik fél rezisztenciapontjának minél pontosabb előzetes feltérképezésével),

- a taktikai tényező ugyanakkor alapvetően kommunikációs természetü: adottnak tekintve a két fél alkupozíciójának (stratégiai) erősségét melyik fél tudja hatékonyabban csökkenteni a saját bizonytalan helyzetét, illetve mennyire sikeresen védi ki a másik fél ugyanerre irányuló szándékát.

\section{Jegyzet}

${ }^{1}$ A szerző köszönettel tartozik Fürjes Balázsnak a kézirathoz füzött fejlesztő javaslataiért.

2 the mythical fixed pie

${ }^{3}$ Magyar fordításban TELA (a tárgyalási egyezség legjobb alternatívája) (Fisher - Ury - Patton, 1997). Tanulmányomban megmaradok a tárgyalási szóhasználatban meghonosodott angol rövidítés mellett.

${ }^{4}$ Itt csak utalok arra a lényeges kérdésre, hogy kinek érdemes kezdeni a nyitó ajánlatok megfogalmazását - ez azonban jelen gondolatmenetünk szempontjából másodlagos, így ennek taglalására nem térek ki.
${ }^{5}$ Ebben a tanulmányban ugyancsak nem térünk ki a kedvező megállapodáshoz kölcsönös engedményekkel közelítő „tárgyalási tojástánc” bemutatására.

${ }^{6}$ probabilistic

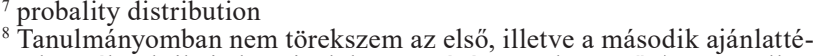
tel egyéb taktikai elemeinek bemutatására, csak az erős/gyenge alkupozícióval való logikai kapcsolatát tisztázom.

\section{Felhasznált Irodalom}

Bakacsi Gy. (2015) : A szervezeti magatartás alapjai. Alaptankönyv bachelor hallgatók számára. Budapest: Semmelweis Kiadó

Bazerman, M. H. (1998) : Judgement in Managerial Decision Making. New York: John Wiley \& Sons

Bazerman, M. H. - Neale, M. A. (1992) : Negotiating Rationally. New York: Free Press

Blahó András (1999): Térjünk a tárgyra. Tárgyalástan. Budapest: Aula Kiadó

Cohen, H. (1980): You Can Negotiate Anything: The World's Best Negotiator Tells You How To Get What You Want. New York: Bantam Books (magyarul: Bármit meg tud tárgyalni. Bagolyvár Könyvkiadó, 1991)

Dawson, R. (1996): Secrets of Power Negotiating. Inside Secrets from a Master Negotiator. New Jersey: Career Press (magyarul: Nyerő tárgyalási taktikák. Egy mestertárgyaló biztos receptjei. Bagolyvár Kiadó, 1999)

Fisher, R. - Ury, W. - Patton, B. (1997) : A sikeres tárgyalás alapjai. Budapest: Bagolyvár Könyvkiadó

Fisher, R. - Ury, W. (1983): Getting to Yes. Negotiating Agreement Without Giving In. New York: Penguin Books (magyarul: A sikeres tárgyalás alapjai. Bagolyvár Könyvkiadó, Budapest, 1997)

Fisher, R. - Brown, S. (1989): Getting Together - Building relationship as we negotiate. New York: Penguin Books

Kissinger, H. (1961): The Necessity of Choice. New York: Harper \& Row

Körösi Mária (2001): Tárgyalástechnikai ismeretek a müszaki menedzsmentben. Üzleti kommunikáció. Budapest: KLZ Bt.

Lawson, K. (2006): Successful Negotiating. (Business Buddies Series). London: New Holland Publishers Ltd. (magyarul: Az eredményes tárgyalás. Alexandra, 2008)

Luecke, R. (2003) : Negotiation. Boston, MA: Harvard Business School Press

Malhotra, D. - Bazerman, M. H. (2007) : Negotiation Genius. New York: Bantam Books

Máté János (1995): Így tárgyalok üzletről. Budapest: Gondverő Könyvkiadó

Neményiné Gyimes Ilona (2002): Hogyan kommunikáljunk tárgyalás közben. Budapest: KJK-KERSZÖV

Neumann, J. - Morgenstern, O. (1944): Theory of games and economic behavior. Princeton: Princeton University Press

Porter, M. (2008): The Five Competitive Forces That Shape Strategy. Harvard Business Review, January

Raiffa, H. - Richardson, J. - Metcalfe, D. (2002) : Negotiation Analysis. The Science and Art of Collabora- 
tive Decision Making. Cambridge, MA: The Belknap Press of Harvard University Press

Raiffa, H. (1982): The Art and Science of Negotiation. How to Resolve Conflicts and Get the Best Out of Bargaining. Cambridge, MA: The Belknap Press of Harvard University Press

Rodgers, M. (2015): Peruasion Equation. The Subtle science of Getting. New York: AMACOM

Scott, B. (1981): The Skills of Negotiaton. Aldershot: Gower Publishing Ltd. (magyarul: A tárgyalás fortélyai. Novotrade, 1988)
Thompson, L. L. (2008): The truth about negotiation. Upper Saddle River, NJ: FT Press Pearson Education, Inc.

Tracy, B. (2013): Negotiation. New York: AMACOM (magyarul: Tárgyalás - Brian Tracy sikerkönyvtára. Trivium Kiadó, Budapest; 2014.)

Ury, W. (1991): Getting past no - Negotiating with difficult people. New York: Bantam Books (magyarul: Tárgyalás nehéz emberekkel. Bagolyvár Könyvkiadó, Budapest, 1995)

Young, O. R. (1975): Bargaining. Formal theories of Negotiation. Chicago: University of Illinois Press 